Original Paper

\title{
Penyuluhan Penggunaan TOGA (Taman Obat Keluarga) Untuk Pengobatan di Desa Senggigi
}

\author{
Nisa Isneni Hanifa ${ }^{1 *}$, Dyke Gita Wirasisya ${ }^{1}$, Raisya Hasina ${ }^{1}$ \\ ${ }^{1}$ Program Studi Farmasi, Fakultas Kedokteran, Universitas Mataram, Mataram, Indonesia
}

DOI: $\underline{10.29303 / \text { jpmpi.v3i2.489 }}$

Sitasi: Hanifa, N., Wirasisya, D., \& Hasina, R. (2020). Penyuluhan Penggunaan TOGA (Taman Obat Keluarga) Untuk Pengobatan di Desa Senggigi. Jurnal Pengabdian Magister Pendidikan IPA, 3(2). doi:https://doi.org/10.29303/jpmpi.v3i2.489

*Corresponding Author: Nisa Isneni Hanifa, Universitas Mataram, Mataram, Indonesia; Email:

nisa.isneni.hanifa@unram.ac.id

\begin{abstract}
Abstrak: The trend of "back to nature" is inseparable from the weakness of treatment using synthetic drugs. Some of them are the side effects caused by the high cost of synthetic medicine that is not friendly to people with low economic level, so knowledge about the use of medicinal plants is very important to be owned by the community. The condition of the people of Senggigi village after the Lombok earthquake in August 2018 was under reconstruction. The land that was used for breeding and maintenance of family medicinal plants (TOGA) was destroyed and damaged. Also, public knowledge about the types of TOGA and the use of plants in the environment around the house which has medicinal properties is also lacking. The solution offered to overcome this problem is to provide knowledge about the types of TOGA and its use for health in the form of counseling to the community. This counseling is done to improve the knowledge and skills of the Senggigi villagers in the use of TOGA for health. This activity is carried out with the delivery of material and discussion, as well as the direct practice of how to process TOGA into preparations that are ready for consumption. The counseling program went well and the people of Senggigi village were very enthusiastic in the discussion. This counseling can increase the knowledge of Senggigi villagers about the use of TOGA as a family treatment seen from the increase in the average post-test score against the pre-test score.
\end{abstract}

Kata Kunci: Counseling; TOGA; Senggigi vilage.

\section{Pendahuluan}

Indonesia merupakan negara yang kaya akan biodiversitas, salah satunya dari kingdom Plantae (tumbuhan). Sebanyak $10 \%$ spesies tumbuhan dunia hidup di Indonesia, dari tumbuhan tingkat rendah hingga tingkat tinggi. Salah satu golongan tumbuhan yang dimiliki Indonesia adalah tanaman obat atau lebih dikenal sebagai tanaman herbal (Alfiani, 2014; Novrinawati, 2016). Dari sekitar 8.000 jenis tanaman obat di Indonesia, baru sekitar 1.200 jenis yang telah dimanfaatkan oleh masyarakat untuk obat tradisional dan jamu (Hidayat, 2006). Pemanfaatan tanaman obat di suatu daerah dapat membantu meningkatkan pembangunan kesehatan daerah dan pendapatan masyarakat melalui keberlangsungan usaha obat tradisional 
ataupun konservasi berbagai sumber daya (Sitepu \& Sutigno, 2011).

Beberapa tahun belakangan ini, ada kecenderungan masyarakat untuk kembali ke alam, atau yang lebih dikenal dengan istilah "back to nature", dimana istilah ini berdampak pada trend pengobatan yang menggunakan bahan dari alam, terkhusus tanaman obat. Trend pengobatan tradisional tidak terlepas dari kelemahan obat sintetis yang memiliki efek samping, kejadian resistensi obat di masyarakat dan harga yang mahal. Hasil analisis data Susenas 2007 yang dilakukan oleh Supardi dan Susyanty (2010) menunjukkan sebanyak $28,1 \%$ dari penduduk Indonesia yang mengeluh sakit dalam kurun waktu sebulan sebelum survey memilih pengobatan sendiri menggunakan obat tradisional. Biaya kesehatan yang semakin mahal menyebabkan obat sintetis menjadi barang mewah bagi sebagian masyarakat menengah kebawah sehingga obat tradisional dipilih sebagai pengobatan alternatif yang dapat diperoleh dari tanaman obat di sekitar kita.

TOGA atau Taman Obat Keluarga adalah sekumpulan tanaman berkhasiat obat untuk kesehatan keluarga yang ditata menjadi sebuah taman dan memiliki nilai keindahan (Kementerian Kesehatan, 2016). TOGA biasanya memanfaatkan sebidang tanah di halaman rumah, kebun maupun ladang untuk budidaya tanaman berkhasiat obat. Kunyit, salam, serai, kencur, dan jeruk nipis adalah beberapa contoh dari tanaman obat yang ada di TOGA (Handayani \& Setyowidodo, 2018). Tanaman ini bisa diolah menjadi obat tradisional yang dapat menjaga kebugaran tubuh dan mengatasi penyakit ringan. Batuk, panas, sakit perut, mencret, gatal, sakit kepala dan nyeri haid adalah beberapa gangguan kesehatan keluarga yang dapat ditangani menggunakan ramuan tanaman dari TOGA (Direktorat Jenderal Bina Kesehatan Masyarakat, 2010).

Desa Senggigi merupakan salah satu desa di kecamatan Batu Layar, kabupaten Lombok Barat yang merupakan desa binaan Fakultas Kedokteran UNRAM. Pengurus PKK desa
Senggigi, bagian Kelompok Kerja (Pokja) 3 yang membidangi tentang lingkungan mengembangkan lahan pembibitan dan pemeliharaan TOGA karena masih sedikit masyarakat yang memiliki TOGA di rumahnya. Pengetahuan masyarakat desa juga masih kurang tentang jenis-jenis dan pemanfaatan TOGA untuk mengatasi gangguan kesehatan. Namun pada tahun 2018, desa Senggigi terkena dampak gempa lombok yang cukup parah. Hampir sebagian besar fasilitas perkantoran desa rusak, termasuk lahan untuk pembibitan tanaman TOGA yang dikembangkan oleh Pokja 3.

Berdasarkan penjelasan di atas, maka perlu diadakan kegiatan inisiasi pembibitan kembali tanaman obat untuk dikembangkan menjadi TOGA dan pemberian informasi tentang pemanfaatan tanaman obat kepada masyarakat desa Senggigi. Pengabdian yang dilakukan oleh Sari, dkk (2019) menunjukkan bahwa pemberian KIE (komunikasi, informasi dan edukasi) kepada masyarakat dapat meningkatkan pengetahuan masyarakat tentang TOGA dan pemanfaatannya. Tujuan khusus dari pengabdian ini adalah inisiasi pembibitan TOGA, penyuluhan dan praktek penggunaan TOGA untuk pengobatan bagi masyarakat desa Senggigi. Program ini bekerjasama dengan mahasiswa KKN Tematik UNRAM yang bertugas di dusun Kerandangan, desa Senggigi.

\section{Metode Pelaksanaan}

Sasaran kegiatan pengabdian kepada masyarakat ini adalah tokoh desa, penggerak PKK dan Posyandu, serta masyarakat desa Senggigi. Metode yang digunakan pada program pengabdian kepada masyarakat ini adalah pendidikan masyarakat dimana kegiatan ini dibagi menjadi dua tahapan, yaitu pembibitan tanaman obat untuk TOGA dan penyuluhan tentang pemanfaatan TOGA untuk pengobatan. Pembibitan tanaman obat untuk TOGA dilakukan dengan cara pemberian bibit dan penanaman tanaman obat di lahan kosong mesjid dusun Kerandangan, desa Senggigi. 
Kegiatan penyuluhan dilakukan dengan metode ceramah dan diskusi mengenai berbagai jenis tanaman obat, ramuan obat untuk mengatasi beberapa penyakit ringan, cara panen dan cara mengolah TOGA menjadi sediaan yang siap dikonsumsi. Keberhasilan kegiatan ini diukur menggunakan ujian tertulis pre dan post test untuk mengukur peningkatan pengetahuan peserta tentang materi yang diberikan.

Penyuluhan disampaikan dengan bantuan media visual (slide presentasi) yang dapat membantu memberikan gambaran tanaman obat. Selain itu, penyuluhan juga dilakukan dengan bantuan media leaflet tentang contoh tanaman TOGA dan manfaatnya (gambar 1). Media leaflet atau media cetak lainnya dapat membantu untuk menjelaskan materi yang disampaikan, selain itu media ini dapat disimpan dalam waktu yang lama.

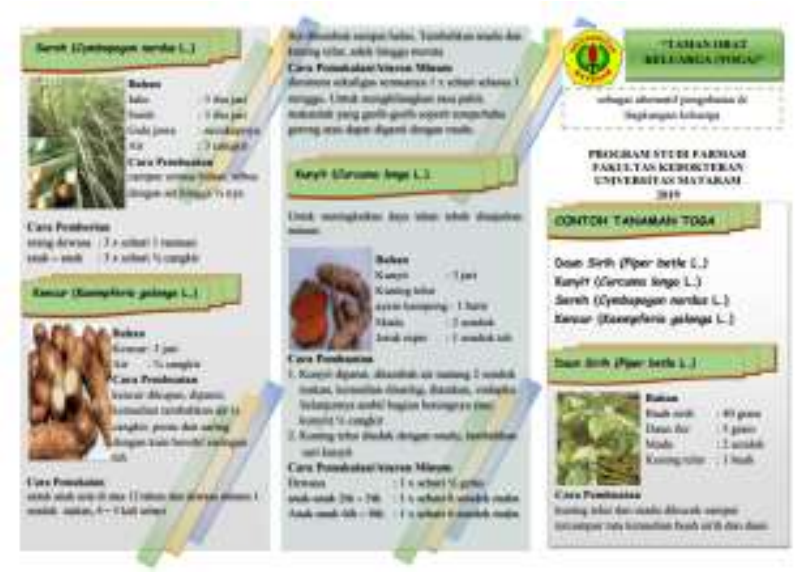

Gambar 1. Leaflet Taman Obat Keluarga (TOGA)

\section{Hasil dan Pembahasan}

Kegiatan penyuluhan penggunaan TOGA ini dimulai dengan inisiasi pembibitan dan penanaman tanaman obat untuk TOGA di lahan kosong di halaman mesjid dusun Kerandangan desa Senggigi (gambar 2). Pembibitan ini dilakukan untuk membudidayakan tanaman obat di suatu lahan, dan setelah pembibitan berhasil, tanaman ini akan disebar ke masyarakat desa Senggigi. Harapannya dengan pembibitan ini, setiap rumah di desa Senggigi nantinya akan memiliki lahan TOGA dan dapat dimanfaatkan sebagai pengobatan mandiri untuk tujuan preventif atau mencegah penyakit. Hal ini sejalan dengan arah kebijakan pelayanan kesehatan tradisional yang mendorong masyarakat untuk memanfaatkan Taman Obat Keluarga (TOGA) untuk merawat kesehatan keluarga secara mandiri dan benar. Dengan melakukan asuhan kesehatan mandiri di tingkat keluarga, masyarakat telah berperan dalam mewujudkan perubahan paradigma kuratif menjadi promotif dan preventif (Kementerian Kesehatan, 2016).

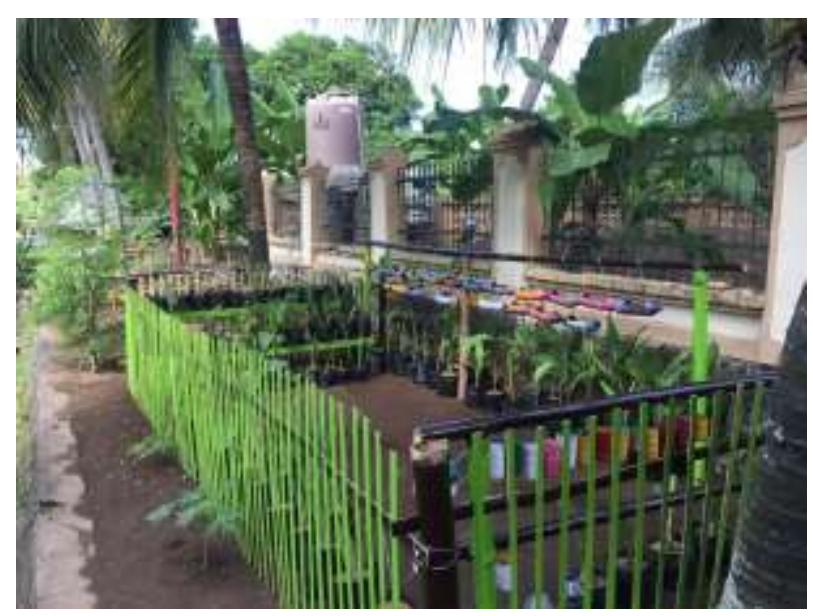

Gambar 2. Lahan pembibitan TOGA di desa Senggigi

Pembibitan tanaman obat ini dilakukan dengan bekerjasama dengan mahasiswa KKN Tematik UNRAM yang juga memiliki program inisiasi TOGA. Sebanyak 17 jenis tanaman obat dibibit di lahan pembibitan desa Senggigi. Adapun tanaman obat yang dibibit dan diberikan ke masyarakat desa senggigi dapat dilihat pada tabel 1. Setiap tanaman obat yang dibibit memiliki manfaat untuk kesehatan.

Acara penyuluhan penggunaan TOGA untuk pengobatan dilakukan pada Sabtu, 27 Juli 2019 di Ruang Ramah Anak Dusun Krandangan, Desa Senggigi yang mudah diakses oleh masyarakat desa Senggigi (gambar 3). Kegiatan ini dihadiri oleh 24 peserta yang terdiri dari tokoh masyarakat desa, kader posyandu, PKK, babinsa, dan perwakilan masyarakat masing-masing dusun. Peserta 
yang hadir sesuai dengan target sasaran yaitu tokoh penting di desa yang dapat menjadi penginisiasi dan pendorong dalam penanaman TOGA di setiap rumah di desa Senggigi.
Karakteristik peserta penyuluhan penggunaan TOGA dapat dilihat pada tabel 2.

\section{Tabel 1. Tanaman obat di lahan pembibitan desa Senggigi}

\begin{tabular}{lll}
\hline No & Nama tanaman & Khasiat \\
\hline 1 & Ciplukan (Physalis angulata) & Sakit kulit, kolesterol, diabetes, nyeri sendi \\
2 & Jahe (Zingiber officinale) & Sakit kepala, penghangat badan \\
3 & Jambu biji (Psidium guajava) & Diare, mencret \\
4 & Kencur (Kaempferia galanga) & Sakit kulit \\
5 & Kumis kucing (Orthosiphon stamineus) & Peluruh air seni \\
6 & Kunyit (Curcuma longa) & Demam, diare, keputihan, gatal-gatal \\
7 & Lengkuas (Alpinia galanga) & Sakit kulit \\
8 & Lengkuas merah (Alpinia purpurata) & Kembung, diare, rematik, batuk \\
9 & Lidah buaya (Aloe vera) & Sakit kepala, sembelit, rambut rontok, diabetes, wasir \\
10 & Lidah mertua (Sansevieria trifasciata) & Diabetes, menyerap polutan, sakit kepala, wasir \\
11 & Mint (Mentha piperita) & Mual muntah, flu, batuk \\
12 & Pandan (Pandanus amaryllifolius) & Meningkatkan nafsu makan, diare, rambut rontok \\
13 & Selasih (Ocimum basilicum) & Insomnia, sakit kepala, sembelit dan kembung \\
14 & Seledri (Apium graveolens) & Hipertensi, asam urat, nyeri sendi \\
15 & Serai (Cymbopogon citratus) & Penghangat badan, sakit perut, nyeri sendi \\
16 & Talas (Colocasia esculenta) & Diabetes, kesehatan mata \\
17 & Tomat (Solanum lycopersicum) & Kesehatan mata, perawatan kulit \\
\hline
\end{tabular}

Sumber: (Direktorat Jenderal Bina Kesehatan Masyarakat, 2010)

Berdasarkan tabel 2, peserta penyuluhan berjenis kelamin laki-laki lebih banyak dari pada perempuan, namun perbedaannya tidak begitu signifikan dimana yang berjenis kelamin laki-laki sebanyak 14 orang $(58,3 \%)$ dan sisanya perempuan. Tingkat pendidikan terakhir peserta mayoritas adalah SLTA $(45,8 \%)$ dan SD $(33,3 \%)$. Hal ini menggambarkan tingkat pendidikan peserta dari masyarakat desa Senggigi cukup baik karena sebesar $45,8 \%$ peserta menyelesaikan wajib belajar 12 tahun. Dari segi usia, peserta terbanyak dari kelompok usia dewasa pertengahan (37,5\%). Perbedaan keikutsertaan masing-masing kelompok usia tidak signifikan, artinya usia tidak mempengaruhi ketertarikan peserta untuk mengikuti penyuluhan tentang TOGA.

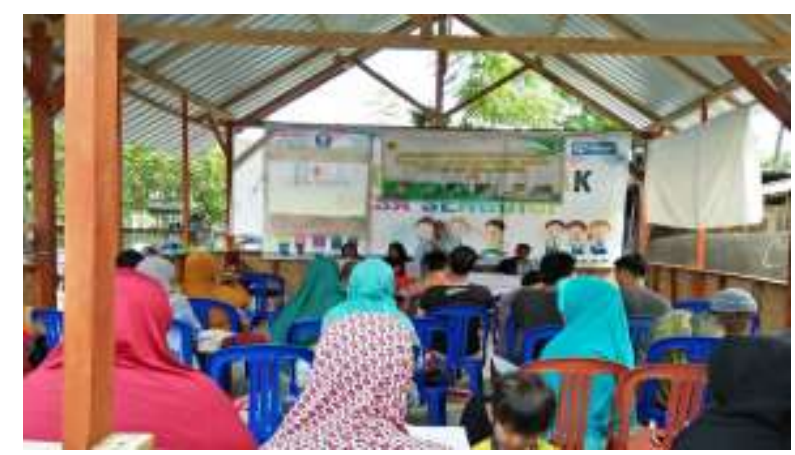

Gambar 3. Acara penyuluhan penggunaan TOGA untuk pengobatan

Materi penyuluhan yang diberikan meliputi pengertian TOGA, kebenaran penggunaan tanaman obat dalam ramuan, cara dan waktu panen, tanaman dan ramuan untuk pengobatan dan pengolahan TOGA. Kebenaran bahan sangat penting untuk diketahui oleh masyarakat karena kesalahan bahan dapat menyebabkan berbedanya khasiat yang ditimbulkan. Pengetahuan tentang waktu dan cara panen yang tepat pada masing-masing bagian tanaman juga harus dimiliki masyarakat agar mendapatkan manfaat yang optimal dari tanaman obat. Menurut Hasan dkk. (2017), 
waktu panen berpengaruh pada kadar senyawa flavonoid daun tempuyung. Masyarakat juga penting untuk mengetahui bagaimana cara pengolahan, karena kesalahan pengolahan dapat berpengaruh pada tidak berefeknya ramuan. Komposisi bahan dalam suatu ramuan perlu diketahui untuk memaksimalkan efek terapi dan mencegah over dose pada ramuan.

Kegiatan penyuluhan penggunaan TOGA untuk pengobatan berjalan lancar dengan antusiasme peserta yang terlihat dari diskusi aktif antara fasilitator dan peserta. Di akhir acara peserta diberikan contoh sediaan sederhana yang diolah dari TOGA, yaitu rebusan batang sereh yang diberikan perasan jeruk nipis. Ramuan sederhana ini sebagai contoh langsung cara sederhana mengolah TOGA menjadi ramuan obat yang berfungsi untuk menghangatkan badan dan melegakan saluran pernafasan.

\section{Tabel 2. Karakteristik Peserta Penyuluhan}

\begin{tabular}{|c|c|c|c|}
\hline No & Karakteristik & Frekuensi (f) & $\begin{array}{l}\text { Persentase } \\
(\%)\end{array}$ \\
\hline \multirow[t]{4}{*}{1} & Jenis Kelamin & & \\
\hline & Laki-laki & 14 & 58,3 \\
\hline & Perempuan & 10 & 41,7 \\
\hline & Total & 24 & 100 \\
\hline \multirow[t]{9}{*}{2} & Tingkat & & \\
\hline & Pendidikan & & \\
\hline & Tidak memilih & 1 & 4,2 \\
\hline & Tidak tamat SD & 1 & 4,2 \\
\hline & $\mathrm{SD}$ & 8 & 33,3 \\
\hline & SLTP & 1 & 4,2 \\
\hline & SLTA & 11 & 45,8 \\
\hline & Perguruan Tinggi & 2 & 8,3 \\
\hline & Total & 24 & 100 \\
\hline \multirow[t]{7}{*}{3} & Usia & & \\
\hline & Remaja (12-25 th) & 5 & 20,8 \\
\hline & $\begin{array}{l}\text { Dewasa Awal } \\
\text { (26-35 th) }\end{array}$ & 7 & 29,2 \\
\hline & Dewasa & 9 & 37,5 \\
\hline & $\begin{array}{l}\text { Pertengahan (36- } \\
45 \text { th) }\end{array}$ & & \\
\hline & $\begin{array}{l}\text { Dewasa Akhir } \\
(46-59 \text { th) }\end{array}$ & 3 & 12,5 \\
\hline & Total & 24 & 100 \\
\hline
\end{tabular}

\section{Ucapan Terimakasih}

Ucapan terima kasih penulis sampaikan kepada Universitas Mataram yang telah memberi dukungan financial terhadap kegiatan pengabdian kepada masyarakat ini. Selain itu, kepada pemerintah desa Senggigi yang telah membantu mensukseskan acara ini. 


\section{Daftar Pustaka}

Alfiani, M. (2014). Keanekaragaman Hayati. Jakarta: Universitas Islam Negeri Syarif Hidayatullah.

Direktorat Jenderal Bina Kesehatan Masyarakat. (2010). Pedoman Kader Pemanfaatan Tanaman Obat Untuk Kesehatan (6th ed.). Jakarta: Kementerian Kesehatan.

Handayani, A. D., \& Setyowidodo, I. (2018). Pemanfaatan Pekarangan Rumah Menjadi Taman Toga Di Desa Bulusari, Tarokan, Kediri. In Proceeding of Community Development (Vol. 2, pp. 754759).

Hasan, F., Aziz, S. A., \& Melati, M. (2017). Perbedaan Waktu Panen Daun terhadap Produksi dan Kadar Flavonoid Tempuyung (Sonchus arvensis L.). J. Hort. Indonesia, 8(2), 136-145.

Hidayat, S. (2006). Tumbuhan Obat Langka di Pulau Jawa: Populasi dan Sebaran. Bogor: Pusat Konservasi Tumbuhan Kebun Raya Boogor, LIPI.

Kementerian Kesehatan. (2016). Peraturan Menteri Kesehatan RI No. 9 Tahun 2016 tentang Upaya Pengembangan Kesehatan Tradisional Melalui Asuhan Mandiri Pemanfaatan Taman Obat Keluarga dan Keterampilan. Jakarta.

Novrinawati, A. D. (2016). Keanekaragaman Tumbuhan Obat pada Jalur Pendakian Lereng Gunung Andong, Dusun Sawit, Kabupaten Magelang, Jawa Tengah. Universitas Sanata Dharma.

Sari, S. M., Ennimay, E., \& Rasyid, T. A. (2019). Pemanfaatan Tanaman Obat Keluarga (TOGA) pada Masyarakat. DinamisiaJurnal Pengabdian Kepada Masyarakat, 3, 1-7.

Sitepu, D., \& Sutigno, P. (2011). Peranan Tanaman Obat dalam Pengembangan Hutan Tanaman. Buletin Penelitian Dan Pengembangan Kehutanan, 2(2), 61-77.

Supardi, S., \& Susyanty, A. L. (2010). Penggunaan Obat Tradisional Dalam Upaya Pengobatan Sendiri di Indonesia
(Analisis Data Susenas 2007). Buletin Penelitian Kesehatan, 38(2), 80-89. 